from a presumption of regularity, it was not conclusive proof of the grant of rights of burial. Under the Local Authority Cemeteries Order 1977, exclusive rights of burial are in the nature of a proprietary right; their assignment can only be done by deed or by bequest. Here, the chancellor was satisfied that the petitioner himself had not sought the transfer and therefore no lawful amendment could be made. The register was wrong. Consequently, the 2016 burial had taken place in a plot reserved for someone else. The chancellor did not accept the reasoning in Re Fairmile Cemetery [2017] ECC Oxf 2 that such a step could not amount to a mistake for the purposes of setting aside the presumption of the permanence of Christian burial as set down in Re Blagdon Cemetery [2002] Fam 299. If Mrs Sutton's family and the council had known of the petitioner's pre-existing right to burial in plot 107 they would not have carried out the interment there - they had made a mistake.

The chancellor went on to consider whether exceptional circumstances had been made out such that a faculty should be granted. The petitioner's status as owner of the exclusive rights of burial is a powerful factor in favour of the grant of a faculty. The availability of other suitable plots for Mrs Sutton's remains also militated in favour of the grant. The attitude of the council was irrelevant to the petition. The strong opposition of the Sutton family, including evidence of the impact on existing mental health issues and the risk that Mr Sutton would not live to see a memorial at his wife's grave, weighed against the grant. Given the availability of alternative burial plots very nearby and the option of the burial of the petitioner's remains in his sister's grave, the chancellor found that exceptional circumstances were not made out and a faculty was refused. [RA]

doi:10.1017/So956618X18000820

\title{
Re Torrisholme Cemetery
}

Blackburn Consistory Court: Hodge Ch, 20 February 2018

[2018] ECC Bla 1

Exhumation - opposition of parent - lapse of time

The petitioner sought a faculty for the exhumation of the remains of her baby son, which had been interred in Lancashire in 2002, for their reburial near her home in West Yorkshire. She had moved to West Yorkshire in 2006. Failing health meant that it was now difficult for her to visit her son's grave as often as she would like and his father had also moved to the area, so that there were now no family members living near the grave. The father strongly objected to the exhumation, saying that he was appalled and disgusted at the suggestion that his son's remains should be disturbed after 15 years to be moved to a place with which he had had no connection. The chancellor applied the test in Re Christ Church, 
Alsager [1999] Fam 142, and then cross-applied as a check the test applicable in the southern province from Re Blagdon Cemetery [2002] Fam 299. The reasons advanced by the petitioner satisfied neither the Alsager test of there being a good and proper reason for the exhumation with which most right-thinking members of the Anglican Church would agree nor the Blagdon test of being exceptional. The father's reaction of horror at the thought of the exhumation and re-interment would be shared by most right-thinking members of the Anglican Church. The petition was dismissed. [RA]

doi:10.1017/So956618X18000832

\author{
Re SS Peter and Paul, Bath (Bath Abbey) \\ Arches Court of Canterbury: George Dean, 11 March 2018 \\ [2018] EACC 2 \\ Costs
}

Having been refused permission to appeal and ordered to pay the petitioners' reasonable costs of responding to the application for permission and the court costs of the application, the Victorian Society made representations that it should not have to bear those costs. It argued that the court should be reluctant to penalise a statutory amenity society, especially where the resources of the church concerned are large compared to the resources of the amenity society. Relying on the decision of Re St Mary, Sherborne [1996] Fam 63, the Victorian Society further argued that the petitioners' costs should not include the costs of employing counsel and solicitors, and, as any other costs would be minimal, none should be awarded. In relation to court costs, referring to its decision in Re St John the Baptist, Penshurst (No 2) (30 March 2015, unreported), the court observed that, where permission to appeal has been granted, there is generally a public interest in the hearing taking place. The position, however, is different where an application to appeal has been refused. There is no public interest in encouraging hopeless applications for permission, rather the opposite. In relation to the petitioners' costs, the court refuted the suggestion that the Sherborne decision included a ruling that legal costs would never be allowed. Statutory amenity societies should not be discouraged from participating in the faculty jurisdiction, including appeals, but, both on a substantive appeal and where permission to appeal has been refused, there is no sound reason why they should be exempt from the usual parties' costs order. The original order for costs was upheld and the Victorian Society ordered to pay the costs of making these further representations. [RA] 